\title{
Mycophenolate mofetil versus cyclophosphamide for therapy of lupus nephritis: an evidence-based case report from systematic reviews and meta- analyses
}

\author{
Laurentius A. Pramono, Birry Karim, Wulyo Rajabto, Parlindungan Siregar, Nanang Sukmana, \\ Bambang Setyohadi
}

Department of Internal Medicine, Faculty of Medicine, Universitas Indonesia, Jakarta, Indonesia

\begin{abstract}
Abstrak
Latar Belakang: Tujuan studi ini adalah membandingkan terapi antara siklofosfamid dan mikofenolat mofetil pada remisi nefritis lupus melalui sebuah laporan kasus berbasis bukti (evidence-based case report) yang diperoleh dari telaah sistematis dan meta-analisis.

Metode: Metode yang digunakan pada studi ini adalah laporan kasus berbasis bukti menggunakan telaah sistematis dan meta-analisis. Pertanyaan klinis adalah manakah terapi imunosupresan yang memberikan hasil lebih baik pada remisi nefritis lupus; siklofosfamid atau mikofenolat mofetil? Untuk menjawab pertanyaan tersebut, kami melakukan pencarian dari situs PubMed dengan kata kunci "lupus nephritis AND mycophenolate mofetil AND cyclophosphamide" dengan batasan telaah sistematis dan/atau meta-analisis, bahasa Inggris, dan hanya melakukan perbandingan secara spesifik terhadap kedua obat.

Hasil: Dari pencarian awal, kami memperoleh 11 artikel telaah sistematis dan/atau meta-analisis terkait terapi nefritis lupus. Satu artikel dieksklusi karena berbahasa Yahudi, empat artikel lain dieksklusi karena tidak spesifik melakukan perbandingan terhadap mikofenolat mofetil dan siklofosfamid sehingga diperoleh enam studi yang ikut serta dalam telaah kritis dan diskusi laporan kasus kami.

Kesimpulan: Berdasarkan bukti-bukti ilmiah yang diperoleh, mikofenolat mofetil memberikan efektivitas yang sama (noninferior) dengan siklofosfamid dalam mencapai remisi pada nefritis lupus, tetapi memiliki tingkat keamanan yang lebih baik daripada siklofosfamid. Pasien pada kasus mendapatkan mikofenolat mofetil dan telah menunjukkan perbaikan secara klinis ke arah remisi pada evaluasi pasca-rawat inap. (Med J Indones 2012;21:44-51)
\end{abstract}

\begin{abstract}
Background: The aim of this case study is to compare the effectiveness between cyclophosphamide and mycophenolate mofetil to achieve remission of lupus nephritis in an evidence-based case report from meta-analyses.

Methods: Method in this case study is evidence-based case report using meta-analyses. Clinical question used in this paper is; which immunosuppressant gives better result in achieving remission in lupus nephritis patient: cyclophosphamide or mycophenolate mofetil? To answer this question, we search the evidence from PubMed with the keywords: "lupus nephritis AND mycophenolate mofetil AND cyclophosphamide" with inclusion criteria of meta-analysis, written in English, and focused comparing cyclophosphamide and mycophenolate mofetil.

Results: From the searching method, we found 11 articles which is relevant. One has been excluded since it written in Hebrew, 4 articles excluded since are not focus answering the clinical question. At the end, 6 studies were included to the critical appraisal step.

Conclusion: Based on the evidences, mycophenolate mofetil is non-inferior to cyclophosphamide in achieving remission in lupus nephritis patients, but with the better safety profile. Patient in our case study get mycophenolate mofetil and shows better clinical condition towards remission as she are evaluated in the outpatient clinic. (Med J Indones 2012;21:44-51)
\end{abstract}

Keywords: Cyclophosphamide, evidence-based case report, lupus nephritis, meta-analysis, mycophenolate mofetil, remission, systematic review

Lupus nephritis, as one of complications, is often seen in systemic lupus erythematosus (SLE) patients..$^{1-3}$ All over the world, the prevalence varied between $31 \%$ and $65 \%$ (average $40 \%$ ) in SLE population. ${ }^{2}$ Other study stated that the complication prevalence was around 50$80 \%$ in SLE population. ${ }^{3}$ Renal involvement is the first manifestation appeared and recognized on SLE patient (3-6\% of SLE patients). Therefore, nephritis and SLE become a union so that firstly, we should evaluate the abnormalities of renal.
Renal involvement in SLE provides bad influence on patient's clinical output directly, such as target organ damage (renal) and also as side effects of the therapy which most of them use steroid and immunosuppressant. ${ }^{4}$ According to the data from The Japanese Society for Dialysis Therapy, there are around 300 patients suffering end-stage renal disease (ESRD) in SLE patients every year. ${ }^{3}$ That is why, the renal involvement develop into one cause of morbidity and mortality in SLE patients. 
Treatment of lupus nephritis should be given after the result of renal biopsy (hystopathology examination) to identify the classification of it. ${ }^{3,5}$ Nevertheless, in certain circumstances when the biopsy cannot be done because either clinical reasons do not support or there is a limitation of hystopathology examination's means, we can classify the lupus nephritis through synthesis of clinical data, blood's laboratory, urinalysis, and 24-hour urine protein., ${ }^{5,6}$ This classification becomes a basic for giving definitive treatment for lupus nephritis patients. $^{5}$

Treatment of lupus nephritis has developed continuously in recent years as the publication's research, especially Randomized Clinical Trial (RCT), made by centres of education and health services around the world. Until now, the concept of treatment includes induction and maintenance. ${ }^{4}$ Fora long timeago, combination of steroid and intravenous cyclophosphamide were used for the treatment of lupus glomerulonephritis. ${ }^{7,8}$ Unfortunately, using of cyclophosphamide is still controversial for some clinicians due to highly toxicity effects, namely suppression on bone marrow, hemorrhagic cystitis, opportunistic infection, malignancy, and also infertility. Thus, other immunosuppressant's agents try to replace cyclophosphamide, for example mycophenolate mofetil (MMF), azathioprine, cyclosporine, and the most recent is tacrolimus. MMF, as a wide spread agent, is often compared with cyclophosphamide.

Various studies, such as case studies, observational, longitudinal design (case control and cohort), and also clinical trials, had been conducted to search a new evidences of the best medical treatment for lupus nephritis. ${ }^{10-12}$ Although every research resulted various clinical parameter and laboratory, all of them had similar outcome namely the remission of lupus nephritis. Some primary indicators, which are often used in the research, are the decrease in urine sediment, the improvement of plasma creatinine levels, and the reduction of urine protein. ${ }^{8-12}$ Meanwhile, indicators becoming secondary target of remission from lupus nephritis are the decrease of titer anti-dsDNA, the increase of albumin levels, and the improvement of complement component. ${ }^{8}$

Until now, there have been 11 systematic reviews and/or meta-analyses made to compare MMF and cyclophosphamide on lupus nephritis patients. ${ }^{13-23}$ However, there is still no formal publication about evidence-based case report (EBCR) related to the best therapy for the remission of lupus nephritis. In addition to that, there is no systematic review from systematic reviews and meta-analyses in one study. We think, these 11 systematic reviews and/or meta-analyses published will be very useful if can be joined in one single review.
The problem formulation in this case report study is; which therapy will provide better effect for remission of lupus nephritis patients between cyclophosphamide and MMF? To answer this question, we used systematic literature study from systematic review and metaanalysis publications and the direct application on patients in this case. This is what we call evidencebased case report (EBCR) design. This approach rarely used on scientific publications in Indonesia, so that it is expected to be able to complete case-report data about the best therapy for remission of lupus nephritis. Moreover, this article may provide new insight for nephritic lupus treatment in Indonesia and all over the world.

\section{CASE RESUME}

In this case, a 20 year-old female patient is reported suffering from SLE with lupus nephritis manifestations. The diagnosis of SLE was established from the previous treatment by using SLE criteria issued by American Rheumatology Association. The diagnosis of lupus nephritis is established by fulfilling these criterias: patient with SLE with urinary protein $\geq 1$ gram $/ 24$ hours with/or hematuria ( $>8$ erythrocyte per low power field) with/ or declining kidney function up to $30 \%$.

Although the patient did not undergo kidney biopsy due to technical problem, this patient is diagnosed with lupus nephritis class III-IV (focal segmental glomerulonephritis or diffuse proliferative glomerulonephritis) based on clinical and laboratory data in accordance with the class mentioned before (hypertension, nephritic syndrome, declining of kidney function, with hematuria and proteinuria). Patient treated as inpatient then outpatient with treatment target of remission of lupus nephritis. This patient is treated with corticosteroid and immunosuppressant. In order to gather the most appropriate immunosuppressant for our patient, thus five steps of EBCR is conducted, consist of formulate the question, searching the evidence, appraise the study, apply the answer, and assess the outcome.

\section{Formulate the question}

Which immunosuppressant therapy give better outcome of remission of lupus nephritis in our patient: cyclophosphamide or mycophenolate mofetil (MMF)?

\section{Searching the evidences}

In order to answer the question above, we conduct a searching in PubMed site by using three key words, they are "lupus nephritis" AND "mycophenolate mofetil" 
AND cyclophosphamide. To attain the best evidence, we limit our search only on systematic reviews or metaanalyses article (the highest level in the evidence based medicine pyramid). Based on this search strategy, we found 11 articles. From these 11 articles, 10 articles were written in English, while 1 article written in Hebrew. From these 10 articles, only 9 articles that can be downloaded for free, while 1 article could not be accessed free. Thus, from the searching step, there were 9 articles that go to the next process.

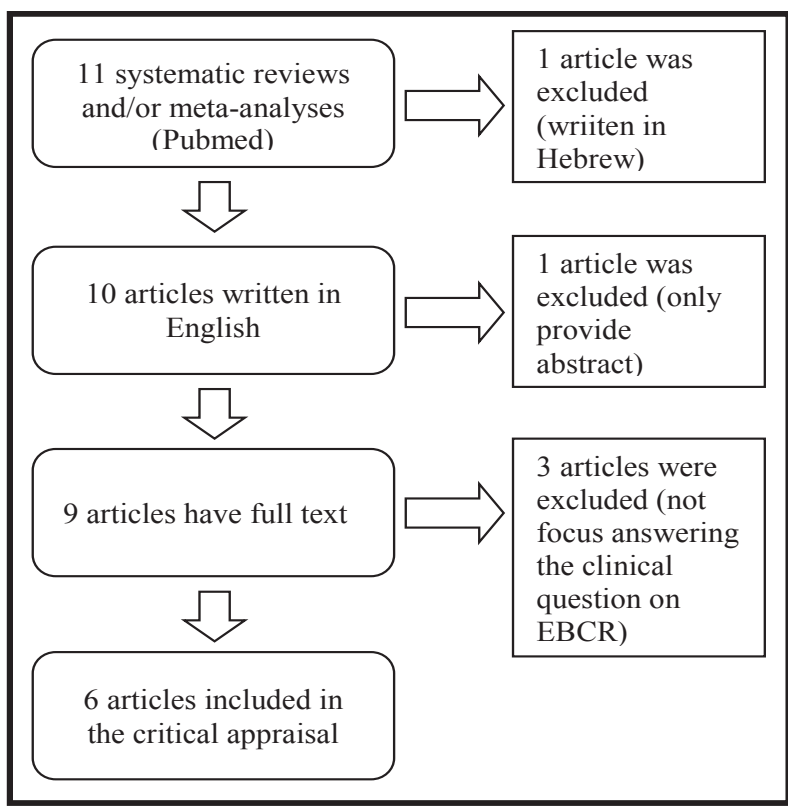

Figure 1. Flowchart of selecting articles used in the EBCR
The next process was selection by reading all the articles (9 articles). The articles that were included in this EBCR were systematic reviews and/or metaanalyses which compare cyclophosphamide and MMF directly. In this step, article written by Navaneethan et al. ${ }^{13}$ was excluded from analysis because it did not compare cyclophosphamide and MMF directly, rather it review systematic review in general of several therapies for lupus nephritis. Articles written by Flanc et al. ${ }^{17}$ and Zhu et al. ${ }^{21}$ were excluded from the analysis because included other therapies in their systematic reviews, which are azathioprine and intravenous immunoglobulin.

Thus, in this EBCR, 6 meta-analysis were included. The 6 articles that goes to the critical appraisal steps were article written by Mohan et al., ${ }^{14}$ Lee et al., ${ }^{15}$, Kamanamool et al., ${ }^{16}$ Moore et al., ${ }^{18}$ Mak et al., ${ }^{19}$ and Walsh et al. ${ }^{20}$ The following figure is regarding the method used to select the article that becomes the reference in this EBCR.

\section{Appraise the studies}

In appraising the scientific evidence of 6 articles, we use the guidance from QUORUM (The Quality of Reporting Meta-analysis) combine with GRADE (Grading of Recommendation Assessment Development and Evaluation) Working Group. In general, both guidance focus on three aspects abbreviated as VIA, which consist of validity, importance, and applicability. The following are the critical appraisal for each of those aspects.

Table 1. Validity of the studies included in the analysis (1)

\begin{tabular}{|c|c|c|c|c|c|}
\hline Study & $\begin{array}{l}\text { Focused } \\
\text { research } \\
\text { question }\end{array}$ & $\begin{array}{l}\text { Selection } \\
\text { criteria }\end{array}$ & Primary outcome & $\begin{array}{l}\text { Design of the } \\
\text { studies }\end{array}$ & Number of studies \\
\hline $\begin{array}{l}\text { Mohan, et al }{ }^{14} \\
\text { (2011) }\end{array}$ & Yes & Yes & $\begin{array}{l}\text { Complete and partial } \\
\text { remission }\end{array}$ & RCT & 7 \\
\hline \multirow[t]{2}{*}{ Lee, et $\mathrm{al}^{15}(2010)$} & \multirow[t]{2}{*}{ Yes } & \multirow[t]{2}{*}{ Yes } & Complete remission & RCT & 5 \\
\hline & & & Partial remission & RCT & 4 \\
\hline \multirow{2}{*}{$\begin{array}{l}\text { Kamanamool, et } \\
\mathrm{al}^{16}(2010)\end{array}$} & \multirow[t]{2}{*}{ Yes } & \multirow[t]{2}{*}{ Yes } & Complete remission & $\mathrm{RCT}$ & 5 \\
\hline & & & Partial remission & RCT & 5 \\
\hline \multirow{2}{*}{$\begin{array}{l}\text { Moore, et al }{ }^{18} \\
(2006)\end{array}$} & \multirow[t]{2}{*}{ Yes } & \multirow[t]{2}{*}{ Yes } & Complete response & $\mathrm{RCT}$ & 4 \\
\hline & & & $\begin{array}{l}\text { Complete or partial } \\
\text { response }\end{array}$ & $\mathrm{RCT}$ & 5 \\
\hline $\begin{array}{l}\text { Mak, et al }{ }^{19} \\
(2009)\end{array}$ & Yes & Yes & $\begin{array}{l}\text { Complete and partial } \\
\text { response }\end{array}$ & RCT & 8 \\
\hline $\begin{array}{l}\text { Walsh, et } \mathrm{al}^{20} \\
(2007)\end{array}$ & Yes & Yes & $\begin{array}{l}\text { Failure to induce } \\
\text { remission (complete or } \\
\text { partial) }\end{array}$ & $\mathrm{RCT}$ & 4 \\
\hline
\end{tabular}


Table 2. Validity of the studies included in the analysis (2)

\begin{tabular}{lcccc}
\hline Study & MMF* & Cyclophosphamide* & Follow up & Remission parameter(s) \\
\hline Mohan, et al & $2 \times 500 \mathrm{mg}-$ & $0,5-2,5 \mathrm{~g} / \mathrm{m}^{2}$ (monthly) & $6-12$ months & Varies between studies \\
& $3 \times 1$ gram (daily) & & & \\
Lee, at al & $1,5-3$ gram (daily) & $0,5-1 \mathrm{~g} / \mathrm{m}^{2}$ (monthly) & $6-12$ months & Varies between studies \\
Kamanamool & $1-3$ gram (daily) & $0,5-2,5 \mathrm{~g} / \mathrm{m}^{2}$ (monthly) & $6-12$ months & Varies between studies \\
Moore, et al & Not reported & Not reported & Not reported & Varies between studies \\
Mak, et al & Not reported & Not reported & Not reported & Varies between studies \\
Walsh, et al & 2-3 gram (daily) & $0,75-2,5 \mathrm{~g} / \mathrm{m}^{2}$ & $6-12$ months & Varies between studies \\
& & (monthly) & & \\
\hline
\end{tabular}

* Note: two groups are similarly treated with corticosteroids

Table 3. Validity of the studies included in the analysis (3)

\begin{tabular}{lcccc}
\hline Study & Number of subjects & Validity appraisal & Reliability assessment & $\begin{array}{c}\text { Similarity of the studies } \\
\text { (homogeneity) }\end{array}$ \\
\hline Mohan, et al & 334 & Yes & No & $57,2 \%$ \\
Lee, at al & 616 & Yes & No & Not reported \\
Kamanamool & 246 & Yes & No & $59,2 \%$ \\
Moore, et al & 638 & No & No & $62,7 \%$ \\
& 266 & & & Not reported \\
Mak, et al & 306 & Yes & No & $40,77 \%$ \\
Walsh, et al & 742 & Yes & No & $0 \%$ \\
\hline
\end{tabular}

Table 4. Importance of the studies included in the analysis

\begin{tabular}{lccccc}
\hline Study & $\begin{array}{c}\text { Overall results } \\
\text { (treatment preference) }\end{array}$ & RR & ARR & NNT & $\begin{array}{c}\text { Precision of the RR } \\
\text { (95\% Confidence Interval) }\end{array}$ \\
\hline Mohan, et al & Not significant different & 1,42 & - & - & $0,87-2,3$ \\
Lee, et al & Not significant different & 1,613 & - & - & $0,908-2,863$ \\
& & 1,031 & - & - & $0,678-1,567$ \\
Kanamool & Not significant different & 1,6 & - & - & $0,87-2,93$ \\
& & 1,2 & - & & $0,97-1,48$ \\
Moore, et al & MMF & 1,5 & $13,2 \%$ & 7,6 & $1,1-2,1$ \\
\multirow{2}{*}{ Mak, et al } & Not significant different & 1,2 & $12,5 \%$ & 8 & $0,03-1,4$ \\
Walsh, et al & MMF & 0,7 & $16,5 \%$ & 6 & 0,166 \\
\hline
\end{tabular}

Table 5. Applicability of the studies included in the analysis

\begin{tabular}{|c|c|c|c|c|c|}
\hline Study & $\begin{array}{l}\text { Apply the } \\
\text { result to } \\
\text { patient care }\end{array}$ & $\begin{array}{l}\text { Considering } \\
\text { all clinical } \\
\text { important } \\
\text { outcomes }\end{array}$ & $\begin{array}{l}\text { Benefit } \\
\text { worth the } \\
\text { harm and } \\
\text { cost }\end{array}$ & $\begin{array}{l}\text { Assessment of } \\
\text { side effect (s) }\end{array}$ & Side effect (s) \\
\hline Mohan, et al & Yes & Yes & Yes & Yes & $\begin{array}{l}\text { Anemia and leucopenia higher in } \\
\text { cyclophosphamide group }\end{array}$ \\
\hline Lee, et al & Yes & Yes & Yes & Yes & $\begin{array}{c}\text { Amenorhea and leucopenia fewer in } \\
\text { MMF group }\end{array}$ \\
\hline Kanamool & Yes & Yes & Yes & Yes & Leucopenia fewer in MMF group \\
\hline Moore, et al & Yes & Yes & Yes & Yes & $\begin{array}{l}\text { Death, hospital admission, serious } \\
\text { infection, leucopenia, amenorhea, and } \\
\text { hair loss fewer in MMF group, but } \\
\text { diarhea higher in MMF group }\end{array}$ \\
\hline Mak, et al & Yes & Yes & Yes & Yes & $\begin{array}{c}\text { Amenorhea and leucopenia fewer in } \\
\text { MMF group, but diarhea higher in } \\
\text { MMF group }\end{array}$ \\
\hline Walsh, et al & Yes & Yes & Yes & Yes & $\begin{array}{l}\text { Amenorhea and leucopenia higher in } \\
\text { cyclophosphamide group }\end{array}$ \\
\hline
\end{tabular}




\section{Apply the answer}

Finding the best immunosuppressant to attain remission in lupus nephritis is one of the main concerns for clinicians and researchers in nephrology and rheumatology field. ${ }^{24,25}$ Chen et al. ${ }^{25}$ stated that "even a partial remission of nephritis is associated with a significantly better patient and renal survival compared with no remission". The amount of meta-analysis made to compare cyclophosphamide and MMF so far showed that there is still controversies remain to be answered by the researchers. The use of cyclophosphamide with steroid for induction and maintenance as the current standard therapy is still unsatisfying, especially regarding its effectiveness, resistance, relapse, and side effects. ${ }^{26,27}$ Thus so far, many are hoping that MMF will replace cyclophosphamide by giving better rate of effectiveness and safety profile.

Cyclophosphamide is an immunosuppressant agent that is being used as the therapy in class III-IV lupus nephritis. Several studies proofed that combination of cyclophospamide with corticosteroid give better effectiveness in reaching remission compared to corticosteroid itself. ${ }^{26}$ Cyclophosphamide therapy has its weakness in term of its toxicity to ovary and bone marrow, also in term of its effectiveness and incidence of relapse and resistant. ${ }^{26,27}$ Two side effects most commonly reported are ovary failures causing amenorrhea and infertility, and leucopenia causing severe infection. These condition make remission induction with cyclophosphamide is still controversial if given to women at reproductive age who still want to be pregnant. ${ }^{27}$

The irreversible side effects of cyclophosphamide require other immunosuppressant to replace the agent. Researchers and clinicians hopes that the candidate for immunosuppressant give better effectiveness in reaching remission in lupus nephritis and lower level of toxicity. ${ }^{28}$ Several agents started to be used for this; some of them were MMF, azathioprine, and tacrolimus. ${ }^{28}$ Among the three agents being used, MMF is the drug used most extensively. Also, in Indonesia, this agent has included in the ASKES (health insurance) program. ${ }^{29}$ Thus, studies that review the effectiveness of MMF or comparing between MMF and cyclophosphamide are often done to give acceptable and applicable scientific evidence.

MMF is an anti-proliferative drugs which first being used one decade ago to prevent the rejection of solid organ transplantation, for example heart, kidney, and liver transplantation. ${ }^{30,31}$ The use of MMF as immunosuppressant in class III-IV lupus nephritis was first reported as case reports, cohorts, and casecontrols, and then clinical trials. In the last decade, so far 11 meta-analyses have been created to observe the effectiveness and side effects of MMF compared with other immunosuppressant, including cyclophosphamide and azathioprine. ${ }^{13-23}$

In this EBCR, 6 meta-analyses are collected which compare the effectiveness and side effects of MMF 1-3 grams (daily) and cyclophosphamide 0,5-2,5 g/ $\mathrm{m}^{2}$ (monthly) with target remission of lupus nephritis within 6-12 month period of observation. The 6 metaanalyses have fulfilled the inclusion criteria, after excluding 5 meta-analyses previously for; 1 article was written in Hebrew, 1 article only provide the abstract, 2 articles do not focus on answering the question in this EBCR (include other immunosuppressant). In all these 6 meta-analyses, critical appraisal was done based on several categories that in general included in VIA (validity, importance, applicability).

Based on 6 meta-analyses included in the analysis, 4 studies were shown to have equal remission effectiveness between cyclophosphamide and MMF, ${ }^{14-16,19}$ while 2 studies showed MMF is more effective compare to cyclophosphamide in reaching remission. ${ }^{18,20}$ All studies have complete and partial remission as their primary outcome. The 4 studies that showed similar effectiveness of both therapies stated that MMF is not inferior (non-inferior) or equal to cyclophosphamide which is being used as standard immunosuppressant, in term of effectiveness.

The use of MMF as replacement therapy for cyclophosphamide is still promising until now, although majority of meta-analyses stated that there is no difference between the two agents in inducing remission. From all studies involved in the analysis, it can be seen that statistically, no significant difference between two drugs in inducing remission of lupus nephritis, whether complete or partial. Two studies that showed superiority of MMF (Moore et al. ${ }^{18}$ and Walsh et al..$^{20}$ ) was done in relatively distant past (published in 2006 and 2007), including 3 same studies, they were Ong et all., ${ }^{30}$ Ginzler et al., ${ }^{8}$ and Chan, et al. ${ }^{33}$ The difference was, in meta analysis written by Moore et al. ${ }^{18}$ they included studies from Contreras et al. ${ }^{34,35}$ while meta-analysis written by Walsh et al. ${ }^{20}$ included study from Flores Suarez-Villa et al. ${ }^{36}$ From Walsh meta-analysis alone, only Ginzler study that show significant difference between the therapy of MMF and cyclophosphamide. However, because the study from Ginzler has stronger weight (samples), the overall result stated that MMF is more effective in inducing remission on his meta-analysis. ${ }^{20}$ 
Meta-analysis by Mak et al. ${ }^{19}$ (published in 2009) included all studies that are included in Moore et al. ${ }^{18}$ and Walsh et al. ${ }^{20}$ meta-analysis (Chan, Ong, Ginzler, Flores Suarez-Villa, and Contreras). On the other hand, Mohan et al., ${ }^{14}$ Kanamool et al., ${ }^{16}$ and Lee et al. ${ }^{15}$ (published in 2011, 2010, and 2010 respectively) included other studies that were conducted later and adding studies that have been included by Mak et al. ${ }^{19}$ and the three of them stated equal effectiveness between MMF and cyclophosphamide. It can be inferred that meta-analysis of Lee et al. ${ }^{15}$ is the latest study and completely assessed other meta-analyses that had been done previously. Meta-analysis by Mohan et al. ${ }^{14}$ is more focused on the geographic influence (race) in the success rate of lupus nephritis remission by using MMF or cyclophosphamide.

Controversies in replacing cyclophosphamide with MMF still remain. Although it fails to shows superiority compared to cyclophosphamide in reaching complete and partial remission in lupus nephritis, MMF might have other superior parameters although not all metaanalyses discuss about that. Navaneethan et al., ${ }^{13}$ one of the studies that is being excluded because analyzed other regiment other than MMF and cyclophosphamide, also stated there were no differences between both regiment in term of risk of end-stage renal disease (ESRD) development and complete remission of nephritis. Although, MMF reduce all-cause mortality rate compared to cyclophosphamide. Similar result was also stated by Moore et al. ${ }^{18}$ in which MMF reduce the mortality and hospitalization rate compared to cyclophosphamide.

Mortality issue in cyclophosphamide and MMF therapy seems to be related to the side effects of both therapies. ${ }^{27}$ In all meta-analysis, it was stated that MMF has better safety profile than cyclophosphamide. ${ }^{14-16,18-20}$ Side effect which is being worried in cyclophosphamide therapy were ovarian toxicity that cause amenorrhea and irreversible infertility, as well as leucopenia that results in severe infection, were significantly lower in MMF group. Side effect that are found more common in MMF group was gastrointestinal side effect such as diarrhea, ${ }^{18,19}$ side effect which is relatively milder compared to infertility and leucopenia. Other side effect that is observed by Mohan et al. ${ }^{14}$ are the occurrence of anemia which is higher in cyclophosphamide group compared to MMF.

For Indonesian rheumatologists, as they are stated in the book of recommendation for systemic lupus erythematosus (SLE), ${ }^{5}$ both MMF and cyclophosphamide can be used for remission induction and maintenance of lupus nephritis. Both have same effectiveness and can be substituted if one of them failed to achieve remission, so does azathioprine, the other immunosuppressant. ${ }^{5}$ In IRA (Indonesian Rheumatology Association) latest meeting (Bandung Clinical Rheumatology Meeting), held in Bandung, February, 9-12 $2^{\text {th }}$ 2012, Soeroso ${ }^{37}$ stated that MMF have similar effectiveness compare with azathioprine and cyclophosphamide, but with the better safety profile. This advantage makes MMF more tolerable in lupus nephritis patients than other immunosuppressant.

The superiority in term of side effects and similar effectiveness in remission makes MMF a better choice compare to cyclophosphamide for lupus nephritis treatment, especially for our patient. MMF as therapy for our patient is a good choice because it gives small risk of infertility and severe infection. Our patient is a young woman who has not married and does not have children yet, thus infertility is a big issue for her and her family. On the other hand, the risk of severe infection during hospitalization can result a fatal outcome to the patient. In addition, MMF now is covered by ASKES and GAKIN program so it can be more acceptable to our patient (our patient get it for free every month). This three consideration makes MMF is the chosen immunosuppressive agent for our patient.

\section{Assess the outcome}

Our patient received induction therapy with MMF $2 \mathrm{x}$ $1000 \mathrm{mg}$ (2 grams daily) combined with corticosteroid (methylprednisolone) with the tapered down dose. In the early evaluation before discharge from the hospital, the titer of anti-dsDNA was decrease from 232,9 to 184 (on treatment day $14^{\text {th }}$ ) and 99.4 (on treatment day $\left.30^{\text {th }}\right)$. As stated in several literatures, high titer of antidsDNA are related to the damages of vital organs in SLE patients. ${ }^{37}$ Thus, it can be the secondary parameter for remission of the disease's activity. ${ }^{8}$

The patient was planned to undergo the induction therapy with the combination for 12 months and urinary protein would be evaluated periodically every 3 months. One month post-hospitalization, patient went for control to the outpatient clinic and the clinical condition of the patient was better, with quantitative urine protein 3.025. This value was the lowest urinary protein so far. Currently, patient can undergo daily activities at home and attain better quality of life.

Two months post-hospitalization (mid of February 2012), the clinical condition was better, as our patient and her mother stated. Now, the methylprednisolone dose is $2 \times 16 \mathrm{mg}(16 \mathrm{mg}-16 \mathrm{mg}-0 \mathrm{mg})$, while MMF dose still 2 x $1000 \mathrm{mg}$ (2 grams daily). Although 
our patient has not check her urine protein this month (because she has been advised to check it every 3 months), her daily activity is increased since she can walk in her house without body crutches. Until now, she still gets MMF (CellCept $\left.{ }^{\circledR}\right)$ monthly (120 tablets 12 strips) from RSCM for free (since it still covered by ASKES and GAKIN program).

In this evidence-based case report(EBCR), we reported a young woman who suffers from lupus nephritis and need induction and maintenance therapy for the remission of her disease. She needs combination of corticosteroid (methylprednisolone) and immunosuppresive agent to achieve remission of lupus nephritis, thus prevent the renal damage and the condition of end-stage renal disease (ESRD). From the critical appraisal focused on 6 meta-analyses collected previously from PubMed with specific criterias, we concluded that MMF has the same effectiveness with cyclophosphamide to achieve remission of lupus nephritis, but with the better safety profile. MMF give smaller risk of infertility and severe infection compared to cyclophosphamide. This agent is also covered by ASKES and GAKIN program so it is more acceptable for our patient. In the short sentence, we choose MMF (CellCept ${ }^{\circledR}$ ) over cyclophosphamide for induction of remission of lupus nephritis in our patient. In the future, further cost-effectiveness analysis (economic analysis) in Indonesian lupus nephritis patients must be made to compare both agents.

\section{Conflict of interest}

We hereby declare that we have no conflict of interest with anyone (especially pharmacy industries) in this EBCR study.

\section{REFERENCES}

1. Bagavant H, Fu SM. Pathogenesis of kidney disease in systemic lupus erythematosus. Curr Opin Rheumatol. 2009;21(5):489-94.

2. Dharmeizar. Perkembangan terbaru dalam penatalaksanaan nefritis lupus. Dalam: Setiyohadi B, Kasjmir YI, editors. Kumpulan makalah temu ilmiah reumatologi 2007. Jakarta: Interna Publishing; 2007. Indonesian.

3. Sada KE, Makino H. Usefulness of ISN/RPS classification of lupus nephritis. J Korean Med Sci. 2009;24(Supp11):S710.

4. Bomback AS, Appel GB. Updates on the treatment of lupus nephritis. J Am Soc Nephrol. 2010;21:2028-35.

5. Perhimpunan Reumatologi Indonesia. Diagnosis dan pengelolaan lupus eritematosus sistemik. Jakarta: IRA; 2011. Indonesian.

6. Weening JJ, D'Agati VD, Schwartz MM, Seshan SV, Alpers CE, Appel GB, et al. The classification of glomerulonephritis in systemic lupus erythematosus revisited. J Am Soc Nephrol. 2004;15:241-50.
7. Bargman JM. How did cyclophosphamide become the drug of choice for lupus nephritis? Nephrol Dial Transplant. 2009;24:381-4.

8. Ginzler EM, Dooley MA, Aranow C, Kim MY, Buyon J, Merril JT, et al. Mycophenolate mofetil or intravenous cyclophosphamide for lupus nephritis. N Engl J Med. 2005;353:2219-28.

9. Adu D. The evidence-based for the treatment of lupus nephritis in the new millenium. Nephrol Dial Transplant. 2001;16:1536-8.

10. Dooley MA, Cosio FG, Nachman PH, Falkenhain ME, Hogan SL, Falk RJ, et al. Mycophenolate mofetil therapy in lupus nephritis: clinical observations. J Am Soc Nephrol. 1999;10:833-9.

11. Joy MS, Hilliard T, Hu Y, Hogan SL, Dooley MA, Falk RJ, et al. Pharmacokinetics of mycophenolic acid in patients with lupus nephritis. Pharmacotherapy. 2009;29(1):7-16.

12. Petri M, Brodsky RA, Jones RJ, Gladstone D, Fillius M, Magder LS. High dose cyclophosphamide versus monthly intravenous cyclophosphamide for systemic lupus erythematosus. Arthritis Rheum. 2010;62(5):1487-93.

13. Navaneethan SD, Viswanathan G, Strippoli GF. Treatment options for proliferative lupus nephritis: an update of clinical trial evidence. Drugs. 2008;68(15):2095-104.

14. Mohan S, Radhakrishnan J. Geographical variation in the response of lupus nephritis to mycophenolate mofetil induction therapy. Clin Nephrol. 2011;75(3):233-41.

15. Lee YH, Woo JH, Choi SJ, Ji JD, Song GG. Induction and maintenance therapy for lupus nephritis: a systematic review and meta-analysis. Lupus. 2010;19:703-10.

16. Kamanamool $N$, McEvoy $M$, Attia J, Ingsathit A, Ngamjanyaporn P, Thakkinstian A. Efficacy and adverse events of mycophenolate mofetil versus cyclophosphamide for induction therapy of lupus nephritis: systematic review and meta-analysis. Medicine. 2010;89(4):227-35.

17. Flanc RS, Roberts MA, Strippoli GFM, Chadban SJ, Kerr PG, Atkins RC. Treatment of diffuse proliferative lupus nephritis: a meta-analysis of randomized controlled trials. Am J Kidney Dis. 2004;43(2):197-208.

18. Moore RA, Derry S. Systematic review and meta-analysis of randomised trials and cohort studies of mycophenolate mofetil in lupus nephritis. Arthritis Res Ther. 2006;8(6):110.

19. Mak A, Cheak AAC, Tan JYS, Su HC, Ho RCM, Lau CS. Mycophenolate mofetil is as efficacious as, but safer than, cyclophosphamide in the treatment of proliferative lupus nephritis: a meta-analysis and meta-regression. Rheumatology. 2009;48:944-52.

20. Walsh M, James M, Jayne D, Tonelli M, Manns BJ, Hemmelgarn BR. Mycophenolate mofetil for induction therapy of lupus nephritis: a systematic review and metaanalysis. Clin J Am Soc Nephrol. 2007;2:968-75.

21. Zhu B, Chen N, Lin Y, Ren H, Zhang W, Wang WM, et al. Mycophenolate mofetil in induction and maintenance therapy of severe lupus nephritis; a meta-analysis of randomized controlled trials. Nephrol Dial Transplant. 2007;22:1933-42.

22. Touma Z, Gladmann DD, Urowitz MB, Beyene J, Uleryk EM, Shah PS. Mycophenolate mofetil for induction treatment of lupus nephritis: a systematic review and metaanalysis (abstract). J Rheumatol. 2011;38(1):69-78.

23. Hochstadt A, Rozman Z, Zandmann-Goddard G. Mycophenolatemofetilasanoveltreatmentforlupusnephritis (abstract). Harefuah (Hebrew). 2011;150(6):542-7. 
24. Chen YE, Korbet SM, Katz RS, Schwartz MM, Lewis EJ. Value of a complete or partial remission in severe lupus nephritis. Clin J Am Soc Nephrol. 2008;3:46-53.

25. Houssiau FA, Vasconcelos C, D'Cruz D, Sebastiani GD, Garrido ER, Danieli MG, et al. Early response to immunosupressive therapy predicts good renal outcome in lupus nephritis. Arthritis Rheum. 2004;50(12):3934-40.

26. Mok CC, Wong RWS, Lai KN. Treatment of severe proliferative lupus nephritis: the current state. Ann Rheum Dis. 2003;62:799-804.

27. Wetzels JFM. Cyclophosphamide-induced gonadal toxicity: a treatment dilemma in patients with lupus nephritis? Neth J Med. 2004;62(10):347-52.

28. Houssiau FA. Management of lupus nephritis: an update. J Am Soc Nephrol. 2004;15:2694-704.

29. Roche Indonesia, ASKES. CellCept ${ }^{\circledR}$ in practice (panduan untuk dokter). Jakarta: PT Roche Indonesia; 2012.

30. Doria A, Iaccarino L, Arienti S, Rampudda ME, Canova MG, Rondinone R, et al. Mycophenolate mofetil and systemic lupus erythematosus. Lupus. 2006;15:44-54.

31. Dooley MA. Mycophenolate mofetil: what role in the treatment of lupus? Lupus. 2006;15:179-82.

32. Ong LM, Hooi LS, Lim TO, Goh BL, Ahmad G, Ghazalli $\mathrm{R}$, et al. Randomized controlled trial of pulse intravenous cyclophosphamide versus mycophenolate mofetil in the induction therapy of proliferative lupus nephritis. Nephrology. 2005;10:504-10.

33. Chan TM, Li FK, Tang CSO, Wong RWS, Fang GX, Ji LY, et al. Efficacy of mycophenolate mofetil in patients with diffuse proliferative lupus nephritis. N Engl J Med. 2000;343:1156-62.

34. Contreras G, Pardo V, Leclercq B, Lenz O, Tozman E, O'Nan P, et al. Sequential therapies for proliferative lupus nephritis. N Engl J Med. 2004;350:971-80.

35. Contreras G, Tozman E, Nahar N, Metz D. Maintenance therapies for proliferative lupus nephritis: mycophenolate mofetil, azathioprine and intravenous cyclophosphamide. Lupus. 2005;14(Suppl 1):S33-38.

36. Flores-Suarez LF, Villa AR. Open randomized trial comparing mycophenolate mofetil versus intravenous cyclophosphamide as induction therapy for severe lupus nephritis. J Am Soc Nephrol. 2004;15.

37. Soeroso J. Evidence-based of mycophenolic acid on systemic lupus erythematosus. Dalam: Wachjudi RG, Pramudiyo R, Dewi S, Hamijoyo L, Rachmadi AR, Najla MA, editors. Himpunan makalah reumatologi klinik Bandung 2012. Bandung: Pusat Informasi Ilmiah Dept IPD FK Unpad/RSHS; 2012. Indonesian. 